to a weakened trematode when it is overtaken by events which do not affect it adversely in its normal state. Flukes do not die even in serious normal infections, when leucocytic infiltrations transform the burrows into large vascular pools, but migrate into the abdominal cavity to die only when death overtakes the host ${ }^{5}$. We must, therefore, abjure the widespread belief that the local tissue reaction of the host in normal infections is directed against the parasite in order to exterminate it. There is now evidence to support the opinion that this reaction is really directed towards the repair of damage caused by flukes burrowing in the liver and may be without effect on the parasites, unless these are weakened in some way and thereby brought into the sphere of influence of the infla mmatory reaction.

The mouse infections were set up to my specifications by Dr. D. L. Hughes, of the Parasitology Group, Allen and Hanburys, Ltd. (Ware), whom I thank. The photographs shown in Fig. 1 were taken by Mr. R. D. Reed of this Department.

Department of Zoology, King's College, London, W.C.2.

1 Dawes, Ben, Nature, 198, 1011 (1963).

2 Dawes, Ben, Parasitology (in the press).

'Hughes, D. L., Ph.D. thesis, Univ. London (1963).

4 Dawes, Ben, J. Helminthol., 36, 11 (1962).

s Dawes, Ben, Parasitology, 53, 135 (1963).

\section{Influence of Acetylsalicyclic Acid on the Body-temperature of Heat-stressed Chickens}

THE oral administration of acetylsalicylic acid or the intra-muscular injections of sodium salicylate were found by $\mathrm{me}^{1}$ to have no influence on the pituitary-adrenal axis of chickens. High levels of acetylsalicylic acid $(0.58 \mathrm{per}$ cent) depressed body-weight while low levels $(0.07$ and 0.15 per cent) did not influence body-weight or prothrombin time. A later report by Hutchins et al. ${ }^{2}$ confirmed that sodium salicylate did not influence the pituitary-adrenal axis in chickens. These workers also reported that immature chicks acclimatized to $105^{\circ} \mathrm{F}$ and fed sodium salicylate had lower body-temperatures than controls not fed sodium salicylate. The purpose of this investigation was to determine the influence of acetylsalicylic acid on the body-temperature of heat-stressed birds.

Two experiments were conducted with New Hampshire. chicks. In the first experiment, 100 birds were fed a basal ration and 100 birds were fed a basal ration containing 0.3 per cent acetyl-salicylic acid. At five days of age, the cloacal temperatures of 11 birds from each pen were recorded with a thermister-thermometer. The birds were then placed in an environmental-walk-in-chamber for $20 \mathrm{~min}$ at $110^{\circ} \mathrm{F}$. This was approximately $20^{\circ} \mathrm{F}$ higher than the normal environmental temperature. Body. temperatures were recorded immediately on removal from the environmental chamber. Body-weights were recorded at 4 weeks of age. In the second trial, New Hampshire chicks were fed a basal diet, a basal plus 0.15 per cent acetylsalicylic acid, and a basal plus 0.60 per cent acetylsalicylic acid. At 8 weeks of age, the cloacal temperatures of 4 birds from each group were recorded before and after heat stress $110^{\circ} \mathrm{F}$ for $20 \mathrm{~min}$. This $110^{\circ} \mathrm{F}$ was about $60^{\circ} \mathrm{F}$ higher than the temperature of the pens in which the birds were raised. Body-weight was also recorded at this time. Analysis of variance ${ }^{3}$ and multiple range test ${ }^{4}$ were the statistical methods used.

Feeding acetylsalicylic acid for 5 or 56 days did not influence normal body-temperature (Table 1). All birds exposed to a sudden rise in temperature experienced an increase in body-temperature. However, the eloacal temperature of heat-stressed birds fed acetylsalicyclic acid was significantly lower than the cloacal temperature
Table 1. Cloacal Temperatures $\left({ }^{\circ} \mathbf{F}\right)$ of Birds fed Acetrlusalicylic Table 1. ClOACAL TEMPERATURES ${ }^{\circ}$ F) OF BIRDS FED ACET

\begin{tabular}{|c|c|c|c|c|}
\hline & Basal & \multicolumn{3}{|c|}{ Acetylsalicylie acid (\%) } \\
\hline & & 0.15 & 0.30 & \\
\hline 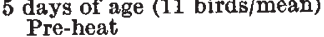 & $105 \cdot 75$ & & $105 \cdot 36$ & \\
\hline Post-heat & $111 \cdot 47$ & & $109 \cdot 25$ & \\
\hline 56 days of age ( 4 birds/mean) & & & & \\
\hline $\begin{array}{l}\text { Pre-heat } \\
\text { Post-heat }\end{array}$ & $106 \cdot 9$ & $\frac{106 \cdot 9}{100 \cdot 2}$ & & $106 \cdot 5$ \\
\hline
\end{tabular}

All means not underscored by the same line differ signiflcantly at the 5 per cent level (ref. 4).

Table 2. Body-Weight and FeEd CoNversion of 8-WEek-OLD BIRD FED ACETYLSALICYLIC ACID

\begin{tabular}{|c|c|c|c|}
\hline \multirow{3}{*}{$\begin{array}{l}\text { Body-weight (g) } \\
\text { Males }\end{array}$} & \multirow{3}{*}{$\begin{array}{c}\text { Basal } \\
1,431(21)\end{array}$} & \multicolumn{2}{|c|}{ Acetylsalicylic acid (\%) } \\
\hline & & $0 \cdot 15$ & 0.60 \\
\hline & & 1,399 & $1,321(18)$ \\
\hline Females & $1,130(30)$ & $\overline{1,170(27)}$ & $\overline{1,051}(21)$ \\
\hline Lb. feed/lb. gain* & $2 \cdot 81$ & $2 \cdot 75$ & $3 \cdot 02$ \\
\hline
\end{tabular}

Numbers in parentheses indicate birds remaining at 8 weeks. 60 birds were started per treatment

were started per treatment

Uncorrected for mortality. at the 5 per cent level (ref. 4 ).

of the controls. No infiuence on body-weight at 4 weeks of age was noted after feeding 0.3 per cent acetylsalicylic acid. On the other hand, $0 \cdot 6$ per cent acetylsalicylic acid significantly reduced the body weight of 8 -week-old birds (Table 2). Twenty-one birds died in the group receiving the highest acetylsalicylic acid while 8 and 9 birds died in the groups receiving 0.15 and 0 per cent acetylsalicylic acid, respectively.

If the thermoregulation in birds resides in the hypothalamus ${ }^{5}$, the antipyretic action of aspirin in birds might be mediated through the hypothalamus. This was shown to be true in monkeys by Guerra and Brobeck ${ }^{6}$.

The greater mortality and significantly smaller bodysize of birds fed $\mathbf{0 . 6}$ per cent acetylsalicylic acid indicate a toxic effect of aspirin at this level. Salicylates may cause a reduced production of high-energy phosphate bonds, resulting in the sacrifice of increasing amounts of substrate to supply the energy required for the phosphorylating processes 7,8 . This would partly explain the reduced bodyweight of our birds in the presence of high levels of aspirin. The toxicity of aspirin may result from a decrease in plasma bicarbonate and an eventual acidosis ${ }^{\circ}$.

Department of Poultry Science,

BruCe GLICK

Mississippi State University,

State College, Mississippi.

1 Glick, Bruce, Ohio J. Sci., 62, 13 (1962).

3 Hutchins, M. O., Newcomer, W. S., and Thayer, R. H., Poultry Sci., 41, 1807 (1962).

${ }^{8}$ Snedecor, G. W., Statistical Methods (Iowa State Univ. Press, 1955).

- Duncan, D. B., Biometrics, 11, 1 (1955).

- King, J. R., and Farner, D. S., Biology and Comparative Physiology of Birds, edit. by Marshall, A. J., 2 (Academic Press, 1961).

- Guerra, G., and Brobeck, J. R., J. Pharmacol. Exp. Therap., 80, 209 (1944).

' Cochran, J. B., Brit. Med. J., ii, 964 (1952).

${ }^{8}$ Smith, M. J. H., Biochem. J., 57, 349 (1954).

- Singer, R. B., Medicine, 33, 1 (1954).

\section{ENTOMOLOGY}

\section{Prothoracic Gland and Gregarious Behaviour in Locusts}

Locust hoppers of the gregarious phase are attracted towards one another and so form groups. Such social aggregation depends on learned reactions and is not shown by hatchlings or by individuals which have lived in isolation (solitary phase). In contrast, the vigorous marching shown by bands of gregarious locusts is not learned and is exhibited in a lesser degree by solitary hoppers ${ }^{1}$. The amount of marching is related to the general level of activity of the animal and is greater in larger than in smaller groups of hoppers. Not only does 